\title{
Review \\ Mesenchymal Stem Cell-Derived Exosomes: The New Frontier for the Treatment of Intervertebral Disc Degeneration
}

\author{
Veronica Tilotta, Gianluca Vadalà *(D), Luca Ambrosio (D), Fabrizio Russo (D), Claudia Cicione (D), \\ Giuseppina Di Giacomo, Rocco Papalia and Vincenzo Denaro
}

check for

updates

Citation: Tilotta, V.; Vadalà, G.; Ambrosio, L.; Russo, F.; Cicione, C.; Di Giacomo, G.; Papalia, R.; Denaro V. Mesenchymal Stem Cell-Derived Exosomes: The New Frontier for the Treatment of Intervertebral Disc Degeneration. Appl. Sci. 2021, 11, 11222. https://doi.org/10.3390/ app112311222

Academic Editor: Benjamin Gantenbein

Received: 18 October 2021 Accepted: 25 November 2021 Published: 26 November 2021

Publisher's Note: MDPI stays neutral with regard to jurisdictional claims in published maps and institutional affiliations.

Copyright: (c) 2021 by the authors. Licensee MDPI, Basel, Switzerland. This article is an open access article distributed under the terms and conditions of the Creative Commons Attribution (CC BY) license (https:/ / creativecommons.org/licenses/by/ $4.0 /)$.
Laboratory for Regenerative Orthopaedics, Department of Orthopaedic and Trauma Surgery, Campus BioMedico University of Rome, Via Alvaro del Portillo 200, 00128 Rome, Italy; v.tilotta@unicampus.it (V.T.); 1.ambrosio@unicampus.it (L.A.); fabrizio.russo@unicampus.it (F.R.); c.cicione@unicampus.it (C.C.); g.digiacomo@unicampus.it (G.D.G.); r.papalia@unicampus.it (R.P.); denaro@unicampus.it (V.D.)

* Correspondence: g.vadala@unicampus.it

\begin{abstract}
Low back pain (LBP) is one of the most frequent symptoms associated with intervertebral disc degeneration (IDD) and affects more than $80 \%$ of the population, with strong psychosocial and economic impacts. The main cause of IDD is a reduction in the proteoglycan content within the nucleus pulposus (NP), eventually leading to the loss of disc hydration, microarchitecture, biochemical and mechanical properties. The use of mesenchymal stem cells (MSCs) has recently arisen as a promising therapy for IDD. According to numerous reports, MSCs mediate their regenerative and immunomodulatory effects mainly through paracrine mechanisms. Recent studies have suggested that extracellular vesicles (EVs) extracted from MSCs may be a promising alternative to cell therapy in regenerative medicine. EVs, including exosomes and microvesicles, are secreted by almost all cell types and have a fundamental role in intercellular communication. Early results have demonstrated the therapeutic potential of MSCs-derived EVs for the treatment of IDD through the promotion of tissue regeneration, cell proliferation, reduction in apoptosis and modulation of the inflammatory response. The aim of this review is to focus on the biological properties, function, and regulatory properties of different signaling pathways of MSCs-derived exosomes, highlighting their potential applicability as an alternative cell-free therapy for IDD.
\end{abstract}

Keywords: extracellular vesicles; exosomes; mesenchymal stem cells; miRNA; low back pain; intervertebral disc degeneration; regenerative medicine

\section{Introduction}

Low back pain (LBP) is one of the most common musculoskeletal symptoms affecting up to $80 \%$ of adults aged between $40-80$ years. Chronic LBP is one of the main causes of disability and loss of work ability with a strong impact on patients' quality of life; additionally, it poses a significant socioeconomic burden on public health worldwide [1] According to a recent global report on the prevalence of LBP, it has been estimated that two thirds of adults are afflicted with LBP at least once in their lives. In addition, the financial burden of LBP in the United States is estimated to exceed $\$ 100$ billion per year, depending on the inevitable effect of changes in work status, prolonged hospitalization, and increased outpatient visits [2-4].

The majority of LBP episodes are associated with intervertebral disc degeneration (IDD). The intervertebral disc (IVD) acts as a shock absorber between the vertebrae while allowing for flexion-extension, lateral flexion, and rotation movements. The IVD is a complex structure connecting two adjacent vertebrae and is composed of the annulus fibrosus (AF), nucleus pulposus (NP) and cartilaginous endplates (CEP) [5]. The AF is a fibro-cartilaginous ring encircling the NP and it consists of concentric lamellae of type I collagen fibers associated with an interlamellar matrix, in which scattered cells with fibroblast-like morphology and phenotype are present [6]. The NP presents a gelatinous 
extracellular matrix (ECM) rich in proteoglycans (mainly aggrecan), type II collagen and other proteins such as elastin and fibronectin. The high level of water content helps maintain disc height and supports the functions of the IVD [7]. The NP cell population has a notochordal origin: notochordal cells (NCs) act as progenitor cells and play an important role in stimulating ECM synthesis by NP cells (NPCs), although in adult human NP tissue the number of NCs diminishes drastically [8]. To preserve IVD architectural features, it is essential to maintain disc cell metabolism and physiological biomechanics, but the avascular and relatively acellular environment of the NP leads to a limited regenerative capacity against stressful and degenerative stimuli. IDD is an age-related disease and is mainly linked to loss of NP hydration and reduction in the proteoglycan content [9]. Current approaches to treat IDD are based on conservative or surgical procedures that aim to relieve the symptoms; however, they are not able to change the natural history of the disease [10].

Recent advances in the understanding of IVD biology have led to an increased interest in the development of novel biological treatments. Growth factors, gene therapy, stem cell transplantation and tissue engineering might support intervertebral disc regeneration [11-16]. The transplantation of mesenchymal stem cells (MSCs), including bone marrow-derived (BM-MSCs) and adipose tissue (Ad-MSCs), has been evaluated in different clinical trials. Although encouraging results have been achieved, there are still several impediments related to the survival and differentiation of transplanted MSCs due to the particularly hostile microenvironment of degenerated IVDs [17]. Moreover, costs related to cell expansion under Good Manufacturing Practice (GMP) conditions and to the quality control guidelines for Advanced Therapy Medical Products (ATMP) limits the large-scale application of a cell therapy strategy.

In the last decade, the interest in extracellular vesicles (EVs) and their therapeutic potential has grown regarding different applications in several fields, including oncology, neurology, cardiology, and orthopedics $[18,19]$. EVs are endogenous nanoparticles released by different cell types and are involved in various physiological mechanisms including apoptosis, tissue regeneration, inflammation, ECM synthesis, cell proliferation and immunomodulation [20]. Based on morphology, biogenesis, size, and content, EVs are generally distinguished in apoptotic bodies, microvesicles and exosomes [21]. One of the contemporary challenges in regenerative medicine is the development of new biology-based therapeutic strategies employing EVs. Indeed, MSCs-derived exosomes have recently demonstrated their potential benefits in preclinical models of cardiovascular diseases, graft-versus-host disease and osteoarthritis [19], while their role in IDD still remains unclear [22].

The aim of this review is to focus on the biological properties, function, and regulatory properties of different signaling pathways of MSCs-derived exosomes, highlighting their potential applicability as an alternative cell-free therapy for IDD.

\section{Intervertebral Disc Degeneration}

IDD is an age-related chronic and progressive process, characterized by a gradual loss of proteoglycans and water content in the NP with a reduction in the disc's capacity to withstand compressive loads [17].

The IVD is an avascular organ, and the supply of nutrition occurs by diffusion from its surrounding vasculature through the CEPs [23]. However, IVD aging and mechanical overload progressively foster endplate calcification and capillary obliteration, thus reducing nutrient delivery to the IVD itself [24]. Due to the lack of blood flow, a hypoxic microenvironment is consequently established with higher $\mathrm{O}_{2}$ concentrations at the surface of the $\mathrm{AF}(19.5 \%)$ and a reduction towards the center of the NP $(0.65 \%)$. However, low oxygen concentration has not been shown to be detrimental for NPC viability [25]. Another factor involved in making the IVD microenvironment hostile is the low glucose concentration, which ranges from about $5 \mathrm{mM}$ at the periphery to about $0.8 \mathrm{mM}$ at the center of the IVD [26]. 
$\mathrm{pH}$ is another crucial parameter in the IVD microenvironment. Local production of lactic acid by IVD maintains a pH between 2 and 6, with significant effects on cell survival and matrix synthesis, as well as on the expression of proinflammatory cytokines and pain-related factors [27]. The main change in NP during IDD is in the imbalance between anabolic factors, such as insulin-like growth factor 1 (IGF-1), growth differentiation factor 6 (GDF-6), transforming growth factor $\beta$ (TGF- $\beta$ ), bone morphogenetic proteins (BMPs) and catabolic enzymes, such as matrix metalloproteinases (MMPs) and a disintegrin and metalloproteinase with thrombospondin motifs (ADAMTS) [28].

Aggrecan, the most abundant proteoglycan in the NP matrix, binds to sulphated glycosaminoglycans (GAGs, e.g., keratan and chondroitin sulfate), and consequently retains hydration and osmotic pressure within the IVD. Negatively charged GAGs regulate the ion balance of the ECM [29]. In a healthy state, osmolarity can range from $430 \mathrm{mOsm} / \mathrm{L}$ (isosmotic pressure) to about $496 \mathrm{mOsm} / \mathrm{L}$ (hyperosmotic pressure) [30]. In degenerative conditions, due to the progressive loss of proteoglycans, the osmolarity of the IVD decreases until it reaches values of about $300 \mathrm{mOsm} / \mathrm{L}$ [31]. Tao et al. reported that high osmolarity can not only decrease the viability and proliferation of disc cells but can also influence the expression levels of collagen type II, SOX-9 and aggrecan in progenitor NPCs [32].

Excessive mechanical loading may be another crucial factor that compromises the biomechanical characteristics of IVD. Static compression stress induces apoptosis, senescence, mitochondrial damage, and matrix catabolism due to a reduction in collagen and aggrecan expression with an increase in MMPs [33]. On the contrary, dynamic compressive loading often triggers an anabolic response and improves the transport of nutrients and growth factors within the NP [34].

The inflammatory response may also contribute to the onset and progression of the degenerative process [35]. The nutritional decrease and accumulation of degraded matrix products promote macrophage-mediated production of pro-inflammatory cytokines such as interleukin (IL)-1 $\beta$ and tumor necrosis factor- $\alpha$ (TNF- $\alpha$ ) through activation of the nuclear factor kappa-light-chain-enhancer of activated B cells (NF-kB) pathway [36]. IL-1 $\beta$ and TNF- $\alpha$ are involved in the progression and initiation of IDD by regulating inflammatory response, IVD cell proliferation, senescence, apoptosis, pyroptosis, autophagy, ECM destruction, and oxidative stress [37]. TNF- $\alpha$ is able to amplify the inflammatory response by stimulating IVD cells to synthesize additional cytokines, including IL-6, IL-8, IL-17, IL-1 $\beta$ and numerous chemokines [38]. IL-1 $\beta$ is expressed at higher levels in degenerated IVDs with an increased production of genes and proteins for the IL-1 receptor. Therefore, although both cytokines are involved in the pathogenesis of IDD, IL-1 $\beta$ may play a more significant role, and could thus be considered an ideal therapeutic target [39]. Tissue aging increases oxidative stress, mitochondrial dysfunction, DNA damage, cell senescence and apoptosis, thus compromising ECM homeostasis [40]. Besides, the viability of NPCs has an important impact on ECM composition. The declining number of cells, their phenotype modification and the inability to withhold compression stresses lead to the deterioration of the AF lamellar architecture and the reduction in ECM synthesis [41,42]. The low metabolic activity of cells and the avascular nature of IVD may explain the inability to self-repair following injury and degeneration [43]. However, recent research has reported the presence of progenitor stem cells in the NP, which may be physiologically responsible, to a certain extent, for endogenous repair of intrinsic insults to IVD integrity.

The natural history of IDD may progress to disc herniation, degenerative spondylolisthesis, spinal instability, and stenosis associated with neurological symptoms such as radiculopathy and/or myelopathy, and surgical intervention is often required [44]. However, the available treatment approaches are not able to arrest IDD; they are only able to relieve accompanying symptoms. Therefore, strenuous research efforts are being made to develop effective strategies that can achieve IVD regeneration. Therefore, the potential use of EVs appears to be a promising therapeutic tool that may support endogenous repair and re-establish the proteoglycan content, thus improving disc hydration and biomechanics. 


\section{MSC Interaction with NP Cells}

Human MSCs are multipotent cells present in almost all tissues such as bone marrow, adipose tissue, skin, lung, synovial membrane, dental pulp, nasal olfactory mucosa, muscle, periosteum, corneal limbus, peripheral blood, endometrial and menstrual blood, uterine cervix, and in fetal/neonatal tissues [9]. Stem cell transplantation represents a promising approach to restore the homeostasis of the degenerated environment of IVD due to the ability of the stem cells to differentiate towards NP-like cells and their immunomodulatory and anti-catabolic effects [14]. In recent decades, several preclinical studies have evaluated the interaction between MSCs and NPCs in vitro [44-46].

Cunha et al. tested the systemic delivery of BM-MSCs in a rat IVD and reported a diminished hypoxic response, risk of herniation and synthesis of cytokines [45]. In an experimental study, Wangler et al. described the homing of MSCs as a potential strategy to prevent the onset of the degenerative cascade in IVDs. They have also evaluated the effect of human MSCs homing in bovine and human disc cells expressing Tie2 (also known as angiopoietin- 1 receptor TEK tyrosine kinase). Tie2 ${ }^{+}$cells represent a progenitor cell population with discogenic differentiation potential. The results showed a proliferative response and reduction in dead cells in both tissues [46].

Our group was one of the first to report the crosstalk mechanism between MSCs and NPCs. In a 3D culture system, where a short distance may improve communication among cells, a paracrine effect of MSCs on NPCs collected from a degenerative disc was demonstrated. Gene expression analysis on both cell types showed that MSCs exerted a trophic effect on NPCs while acquiring a chondrogenic phenotype due to the communication with NPCs [47]. In another similar in vitro study, we highlighted the significant increase in GAG content and proliferation of NPCs when co-cultured with MSCs [48].

In the last decade, intradiscal stem cell therapy for IDD has provoked increasing interest in the field. Since cell isolation and implantation procedures can be safely performed in a sterile environment and with low immunogenicity, both autologous and allogeneic transplants can be used [49]. In a pilot study by Orozco et al., 10 patients with chronic LBP were injected with autologous BM-MSCs for the treatment of lumbar disc degeneration. Three months after surgery, LBP and disability were significantly reduced. Despite the small number of patients, this study demonstrated that intradiscal BM-MSC transplantation was a safe procedure with a promising role in the treatment of IDD [50]. Similarly, a randomized controlled trial including 24 patients with lumbar IDD reported a significant reduction in pain in the lumbar region and reduced disability one year after BM-MSC allogeneic transplant, whereas the control group, who received a sham infiltration within the paravertebral musculature did not show any improvement [51].

Earlier research has proved that MSCs secrete bioactive molecules and trophic factors such as soluble proteins, nucleic acids, lipids and EVs, and highlights their anti-apoptotic, immunomodulatory, angiogenetic, anti-fibrotic functions and differentiation capacity, probably mediated by paracrine mechanisms [52-54]. The products released by MSCs in vitro and in vivo constitute their secretome [55]. In a bovine ex vivo model, Teixeira et al. investigated the immunomodulatory paracrine effect of BM-MSCs in the proinflammatory IDD microenvironment. While MSCs viability was not influenced, cell migration increased, collagen type II and aggrecan levels remained stable while inflammatory cytokines IL-6, IL- 8 and TNF- $\alpha$ were downregulated by MSCs in IL-1 $\beta$-stimulated IVDs [56]. Furthermore, MSCs have been shown to migrate from their niches to damaged sites in response to injury, immune or physicochemical signals. This physiological mechanism of MSCs recruitment or homing may play a role in promoting the repair of different musculoskeletal tissues [57].

Interestingly, recent studies investigated the cross-talk between MSCs and NPCs through trophic factors [58]. Shim et al. investigated paracrine interactions in a co-culture system by isolating MSCs, AF and NPCs from the same donor. The characterization revealed an increase in mRNA levels expression of ECM genes (SOX9, COL2A1 and ACAN), the downregulation of MMPs and ADAMTS, as well as the inhibition of the production of pro-inflammatory factors compared to monocultures [59]. Li et al. also 
employed a co-culture system to understand the influence of BM-MSCs on TNF- $\alpha$-induced NPC degeneration and reported an increase in cell proliferation and type II collagen production, a decrease in MMP-9 expression, and reduced TGF $\beta$ /NF- $\mathrm{kB}$ signaling in pro-senescent NPCs. Premature senescence and aging of NPCs were restored in the coculture system [60]. Even though the regenerative, anabolic, and inflammatory-modulating properties of MSCs have been demonstrated in several investigations, many aspects are still unclear.

The harsh microenvironment with the absence of vasculature, hypoxia, low glucose concentration, acidity, hyperosmolarity and continuous mechanical stimulation plays a crucial role for cell survival and their regenerative potential [61]. Furthermore, MSC implantation may further impair the balance between the nutrient supply and demand of resident disc cells, thus causing cell death. Miguélez-Rivera et al. investigated the effectiveness of a conditioned medium (CM) derived from the culture of MSCs in a rat IDD model. MSC-derived CM has shown immunomodulatory and anti-inflammatory properties in a detrimental environment by down-regulating the expression levels of pro-inflammatory cytokines such as IL-1 $\beta$, IL-6, IL-17 and TNF [62].

Although MSC-based therapy may be considered an attractive and a safe option, there are still unsolved issues. In addition to the abovementioned shortcomings, MSCs require a long and expensive process for in vitro expansion according to the minimum standard to guarantee controlled conditions in production processes and clinical procedures [63].

\section{Extracellular Vesicles}

EVs were discovered in 1987 by Johnstone et al. during the in vitro maturation of reticulocytes in culture [64]. Secreted EVs are a group of cell-derived membranous structures with biological potential in numerous human diseases (e.g., cancer, neurodegenerative and musculoskeletal disorders). Collection, pre-processing, separation, concentration, and characterization of EVs have been widely studied. In 2018, the International Society for Extracellular Vesicles (ISEV) proposed the Minimal Information for Studies of Extracellular Vesicles (MISEV) as an update of general knowledges presented in MISEV 2014 guidelines to allow the reproducibility of results among investigators [65].

\subsection{Size and Morphology}

The determining factors that discriminate the different classes of EVs are size, morphology, origin and content (Table 1) [66].

Table 1. General features of exosomes, microvesicles and apoptotic bodies.

\begin{tabular}{|c|c|c|c|}
\hline & Exosomes & Microvesicles & Apoptotic Bodies \\
\hline Size & $30-100 \mathrm{~nm}$ & 50-1000 nm & $800-5000 \mathrm{~nm}$ \\
\hline Morphology & Cup-shaped & Spherical structures & Heterogeneous \\
\hline Content & $\begin{array}{c}\text { Coding RNA, } \\
\text { noncoding RNA, } \\
\text { proteins, lipids, DNA }\end{array}$ & $\begin{array}{l}\text { RNA, proteins, } \\
\text { lipids, cytosol }\end{array}$ & $\begin{array}{c}\text { Proteins, lipids, DNA, } \\
\text { RNA, cytosol }\end{array}$ \\
\hline Biogenesis & $\begin{array}{l}\text { By exocytosis in } \\
\text { which ILVs within the } \\
\text { lumen of MVEs fuse } \\
\text { with the plasma } \\
\text { membrane to } \\
\text { release ILVs }\end{array}$ & $\begin{array}{l}\text { By outward budding } \\
\text { and fission of the } \\
\text { plasma membrane } \\
\text { and the sub-sequent } \\
\text { release of vesicles into } \\
\text { the } \\
\text { extracellular space }\end{array}$ & $\begin{array}{l}\text { Outward blebbing of } \\
\text { the cell membrane }\end{array}$ \\
\hline
\end{tabular}

ILVs = intraluminal vesicles; MVEs = multivesicular endosomes.

It is possible to distinguish three main EV categories: apoptotic bodies, microvesicles and exosomes (Figure 1) [67]. 


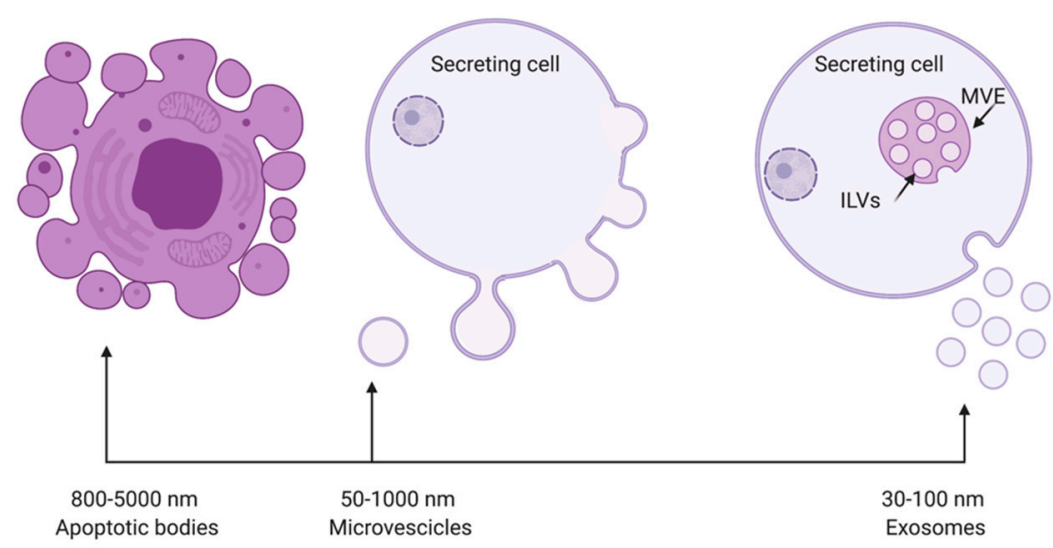

Figure 1. Extracellular vesicles distinguished by size: apoptotic bodies (800-5000 nm), microvesicles (50-1000 nm) and exosomes (30-100 nm). Created with BioRender.com (accessed on 10 October 2021).

Apoptotic bodies have a size range of $800-5000 \mathrm{~nm}$ with a heterogeneous morphology. They also include smaller vesicles known as apoptotic cell-derived microparticles or apoptotic blebs released by apoptotic cells [66].

Microvesicles were originally described as "platelet dust", as they were first isolated from platelets [68]. They have a diameter of $50-1000 \mathrm{~nm}$, a spherical structure, and are expelled through exocytosis of the plasma membrane [69].

The last class of vesicles are smaller than those mentioned above, have a size range of 30-100 nm, a cup-shaped morphology and are called exosomes [70]. However, some studies have shown that the cup-shaped morphology could be an experimental artefact and the overlapping range of size may lead to unclear terminology [71]. Further isolation and characterization protocols are expected to establish an appropriate classification and nomenclature [72].

\subsection{Content and Biogenesis}

Cell type and the physiological or pathological state of the parent cell may influence its EV content [73]. To date, the interest in EVs has grown exponentially due to their abundant presence in body fluids, their wide range of regulatory functions and their capacity as vehicles for DNA, mRNAs, miRNAs, proteins, and lipids involved in intercellular communication (Figure 2) [74].

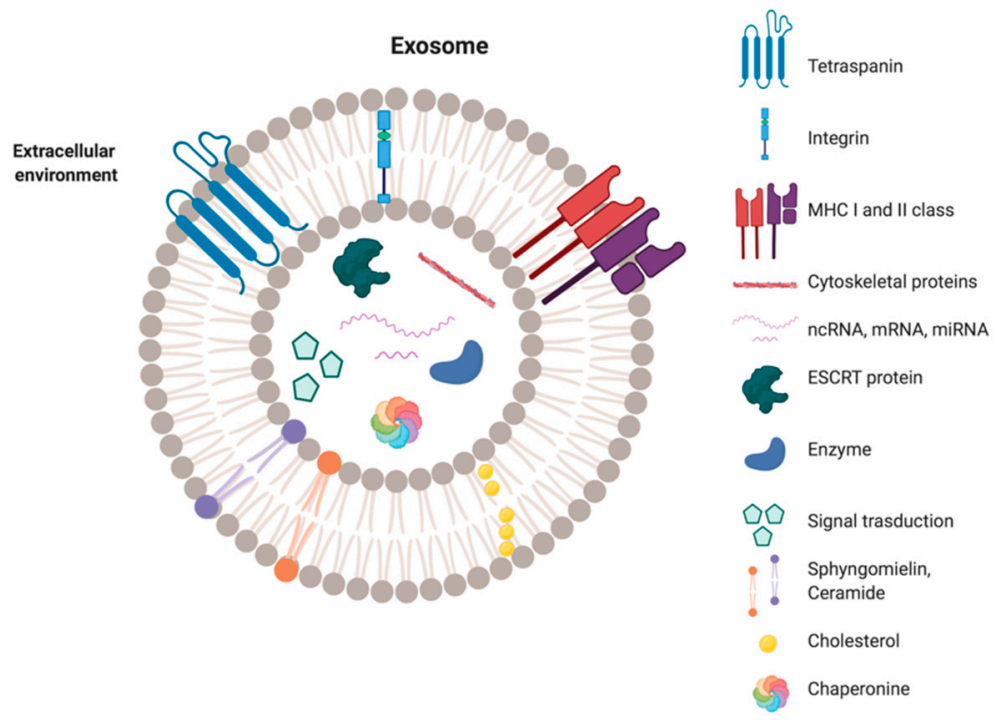

Figure 2. Exosomal composition in terms of bioactive molecules: lipids, proteins, and nucleic acids. Created with BioRender.com (accessed on 10 October 2021). 
The protein content of EVs is often used as a marker to recognize EV sub-populations. Exosomes are rich in endosome-associated proteins (e.g., Rab GTPases, SNAREs, annexins, and flotillin), proteins involved in EV biogenesis (e.g., Alix and Tsg101), transmembrane proteins composed of four domains such as tetraspanins (CD63, CD81, CD9 and CD82), major histocompatibility complex (MHC) molecules and cytosolic proteins such as heat shock proteins [20]. EVs also present a lipidic component. Exosomes are enriched in cholesterol, sphingomyelin, phosphatidylcholine, and phosphatidylethanolamine, as well as proteins associated to lipid rafts such as glycosylphosphatidylinositol-anchored proteins and flotillin. Nevertheless, the lipid content of microvesicles is less known than exosomes and is primarily involved in their budding from the plasma membrane [75]. Regarding nucleic acids, it was reported that microvesicles and exosomes carry single-stranded DNA (ssDNA), double-stranded DNA (dsDNA), genomic DNA, mitochondrial DNA, and reverse-transcribed complementary DNAs [76,77]. On the other hand, EVs can deliver mRNA, mRNA fragments, long non-coding RNA (lnRNA), miRNA, ribosomal RNA (rRNA) and fragments of tRNA, vault- and Y-RNA [78]. More importantly, miRNAs may act on the behavior of recipient cells by regulating gene expression, immune response, and additional physiological processes $[79,80]$.

Exosomes and microvesicles have two different pathways of biogenesis. They are constantly produced by viable cells, while apoptotic bodies are released exclusively during the apoptotic phase of the cell cycle [81]. Whereas the releasing mechanisms of apoptotic bodies from the cell membrane have been widely elucidated, those related to microvesicles have been investigated only recently. Microvesicles are formed by fusion with the internal side of the plasma membrane and requires several rearrangements within the membrane itself such as reorganization of lipid and protein components and $\mathrm{Ca}^{2+}$ levels $[82,83]$. It has been reported that a reduction in cholesterol in microvesicles may compromise their generation in activated neutrophils [84]. In addition, the small GTPase family Rho and the protein kinase associated with Rho (ROCK) induce the biogenesis of microvesicles in various populations of cancer cells by regulating the activity of cytoskeletal components such as actin [85].

Exosomes are defined as intraluminal vesicles (ILVs) formed by the invagination of the endosomal membrane during the maturation of multivesicular endosomes (MVEs). This process leads to the acquisition of cargo and emission of vesicles in the lumen through particular sorting machineries (Figure 3) [86].
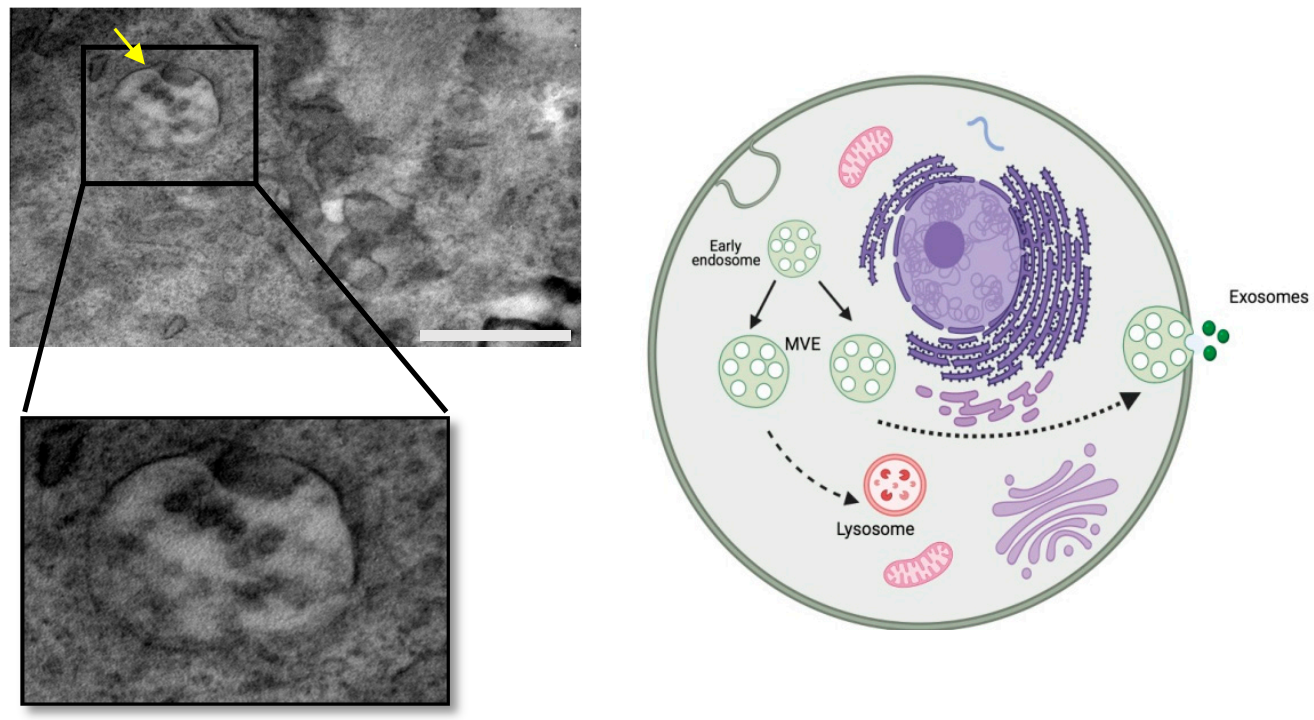

Figure 3. Visualization of MVEs by electron microscopy (scale bar $=1 \mu \mathrm{m}$ ). Biogenesis process of ILVs by budding into early endosomes. MVEs release exosomes by fusion with the plasma membrane or fuse with lysosomes. ILVs = intraluminal vesicles; MVEs = multivesicular endosomes. Created with BioRender.com (accessed on 10 October 2021). 
The discovery of the endosomal sorting complex required for transport (ESCRT) machinery was important as it seems to be a fundamental component in several cell types for the generation of MVEs and ILVs $[87,88]$. The first step is the enrolling of ESCRT-0 subunits, which select cargo in a ubiquitin-dependent manner; ESCRT-I and ESCRT-II are involved in budding endosomal membrane formation, and ESCRT-III is deputed to ILV scission and recycling of the ESCRT machinery [89]. Tumor susceptibility gene 101 (TSG101) and ALIX are two important members of the ESCRT complex discovered by Théry et al. in a proteomic analysis of mouse dendritic cell-derived exosomes [90].

Exosomes can also be formed through an ESCRT-independent mechanism. The sphingolipid ceramide plays a role by creating a spontaneous negative curvature in the membrane leaflets of MVEs to shape ILVs [91]. The formation and the sorting of ILV cargo can also be regulated by the syndecan-syntenin-ALIX pathway. Indeed, syndecan heparan sulphate proteoglycans are connected to their cytoplasmic adaptor syntenin, which interacts with ALIX hence promoting endosomal membrane budding [92].

Finally, exosomal surface proteins belonging to the tetraspanine family, such as CD63 CD81, CD82 and CD9 or heat shock protein (Hsp70), may control ESCRT-independent exosomes biogenesis $[93,94]$. Intracellular vesicular trafficking, fusion with the plasma membrane, and consequently, exosome secretion are driven by Rab GTPases proteins [95]. Mechanisms regulating the sorting of nucleic acids in exosomes are still not known.

In summary, microvesicles bud directly from the plasma membrane, while exosomes are firstly incorporated into the endosomal vesicles and then released into the extracellular milieu by fusion of MVEs with the plasma membrane. Once released, EVs are absorbed by neighboring cells by endocytosis, phagocytosis, pinocytosis, or fusion of membranes. Ligands on the extracellular vesicle membrane can also bind to a receptor on target cells to thereby induce an intracellular signal [96].

\section{Exosome Therapy for IVD Regeneration}

Emerging cell therapies have demonstrated promising results by supplementing damaged IVDs with stem cells harvested from different sources [97]. Despite this, there is a growing interest in cell-free therapy. Recent research has proposed that exosomes derived from different tissues such as bone marrow and adipose tissue could represent an emerging tool in regenerative medicine [98]. The use of MSC-derived exosomes may offer several advantages. In fact, they do not require tissue engraftment but present high biocompatibility, low immunogenicity and toxicity, less oncogenic potential and substantial economic benefits compared to cell therapy. Such aspects may promote the use of MSCs-derived exosomes for IVD regeneration as an attractive alternative to intradiscal cell therapy [99].

However, before the exploitation and application of exosomes, it is necessary to isolate them efficiently from biological fluids or supernatants from in vitro cell cultures $[100,101]$. Ultracentrifugation is the most used technique and is often coupled with ultrafiltration to improve the purity of the sample, although this provides the risk of nanoparticle deformation [102,103]. Other sophisticated approaches include tangential flow filtration, dimensional exclusion chromatography and polymeric precipitation [104-106]. Several methods are available for exosome characterization. Transmission electron microscopy (TEM) and scanning electron microscopy (SEM) are often employed to verify their morphology. Nanoparticle tracking analyzers (NTA) measure the diameter size and specific EV markers (CD9, CD63, CD81, TSG101 and ALIX) can be identified through flow cytometry [107].

The role of exosomes has been evaluated with regards to ECM synthesis, metabolic dysfunction, anti-apoptotic processes, inflammation, and wound healing (Table 2) [108,109]. 
Table 2. Summary of available evidence on the role of EVs in IDD.

\begin{tabular}{|c|c|c|}
\hline Authors & Type of Study & Potential Role of EVs \\
\hline Liao et al. [110] & In vitro/In vivo & $\begin{array}{c}\text { Modulation of ER stress and } \\
\text { reduction in NPC apoptosis } \\
\text { during IDD }\end{array}$ \\
\hline Lan et al. [111] & In vitro/In vivo & $\begin{array}{l}\text { Induction of NPC exosomes } \\
\text { on the differentiation of MSCs } \\
\text { into NP-like cells }\end{array}$ \\
\hline Lu et al. [112] & In vitro & $\begin{array}{c}\text { Intercellular communication } \\
\text { between BM-MSCs and NPCs } \\
\text { after exosomal reciprocal } \\
\text { up-take }\end{array}$ \\
\hline Xia et al. [113] & In vitro/In vivo & $\begin{array}{c}\text { Restorative effects of } \\
\text { exosomes on } \mathrm{H}_{2} \mathrm{O}_{2} \text {-induced } \\
\text { NPC inflammation, ROS } \\
\text { production and } \\
\text { mitochondrial dysfunction }\end{array}$ \\
\hline Hingert et al. [114] & In vitro & $\begin{array}{c}\text { Stimulation of ECM } \\
\text { production, cell proliferation } \\
\text { and reduction in cell apoptosis } \\
\text { in disc cells after treatment } \\
\text { with EVs from hMSCs }\end{array}$ \\
\hline
\end{tabular}

Li et al. [115] In vitro

Li et al. [116]

In vitro

Luo et al. [117]

In vitro/In vivo

Protective effect on human NPCs in the IVD acid environment

BM-MSC-exosomes promoted AF cells proliferation

CEP stem cell-derived exosomes decrease the apoptosis rate of NPCs in vitro and activated autophagy in vivo

Stimulation of the migration of CEP stem cells into the IVD Luo et al. [118] In vitro/In vivo and their differentiation into NPCs via autocrine exosomes release

Engineered EVs deliver Tang et al. [119] In vitro/In vivo FOXF1 and reprogram human NPCs in vitro and mouse IVD cells in vivo

\section{AF-derived exosomes mediate} Sun et al. [120] In vitro intercellular communication between AF cells and HUVECs

\section{Results}

Attenuation of ER stress-induced apoptosis by activating AKT and ERK signaling in vitro and in a rat tail model

NPC exosomes play a key role in the differentiation of MSCs into NP-like cells through inhibition of the Notch1 pathway

Improvement in BM-MSC migration and differentiation to a NP-like phenotype, NPC proliferation and ECM production

Anti-inflammatory role in pathological NPCs and reversion of the damaged mitochondria. In the rabbit model exosomes significantly prevented IDD

hMSCs-derived EVs increased cell viability and stimulated chondrogenesis in NPCs from degenerated IVDs

MSC-derived exosomes promote the expression of ECM, protecting NPCs from acidic $\mathrm{pH}$-induced damage and apoptosis

Suppression of IL-1 $\beta$-induced inflammation, apoptosis rate and autophagy in AF cells

Reduction in the apoptotic NPCs after treatment with healthy exosomes compared to degenerated exosomes and attenuated IDD via activation of the AKT and autophagy pathways

CEP stem cell-derived exosomes promoted invasion, migration, and differentiation of cartilage endplate stem cells by autocrine exosomes via the HIF-1 $\alpha /$ Wnt pathway

Upregulation of healthy NP markers (FOXF1, KRT19), downregulation of IL-1 $\beta$ and IL-6, MMP13, and NGF, with significant increases of GAG in human NPCs

AF- derived exosomes could be phagocytosed by HUVECs regulating cell migration and inflammation with a proangiogenic effect in IDD

$\mathrm{AF}=$ annulus fibrosus; $\mathrm{BM}-\mathrm{MSC}$ = bone marrow-derived mesenchymal stem cells; $\mathrm{CEP}=$ cartilaginous endplate; $\mathrm{ECM}=$ extracellular matrix; $\mathrm{ER}=$ endoplasmic reticulum; $\mathrm{EVs}$ = extracellular vesicles; GAG = glycosaminoglycan; hMSCs = human mesenchymal stem cells; HUVECs = human umbilical vein endothelial cells; IDD = intervertebral disc degeneration; IL = interleukin; IVD = intervertebral disc; $\mathrm{MMP}=$ matrix metalloproteinase; $\mathrm{MSC}=$ mesenchymal stem cell; $\mathrm{NGF}=$ nerve growth factor; $\mathrm{NP}=$ nucleus pulposus; $\mathrm{NPC}=$ nucleopulpocyte; $\mathrm{ROS}=$ reactive oxygen species . 
The beneficial effect of MSC-derived exosomes on NPCs in acidic conditions has been recently demonstrated. BM-MSC-exosomes increased proliferation and attenuated the apoptosis of NPCs and enhanced the expression of ECM components [115]. Moreover, exosomes are able to inhibit IL-1 $\beta$-induced inflammation and apoptosis in AF cells and they promote cell proliferation [116]. On the other hand, Liu et al. identified various similarities between CEP stem cells and MSCs, including their capacity to communicate with IVD cells by secreting extracellular vesicles [121]. Indeed, IVD repair may be promoted by CEP stem cell exosomes by inhibiting NPC apoptosis and encouraging the migration of CEP stem cells into the IVD and differentiate into NPCs via autocrine mechanisms $[117,118]$. AF-derived exosomes have also showed a protective effect in IDD [120]. Aging and degenerative tissues usually accumulate in endoplasmic reticulum (ER) advanced glycation end-products (AGEs) related to inflammation, cell death, metabolic dysfunction, and stress [122,123]. Liao et al. found that the injection of MSCs-derived exosomes in an in vivo rat IDD model modulated ER stress by protecting NPCs against cell death and ameliorating IDD through an attenuation of AGE-induced ER stress mediated by AKT and ERK pathways [110]. Exosomes may also induce differentiation of stem cells towards different phenotypes, although the underlying mechanisms are still unknown. It was reported that the inhibition of Notch1 may promote exosome-induced differentiation of MSCs into NP-like cells in vitro [111]. Lu et al. analyzed exosomes secreted by both NP cells and BM-MSCs in a co-culture system. They highlighted that NPC-derived exosomes induced BM-MSC differentiation towards a NP-like phenotype, whereas BM-MSC-derived exosomes promoted NPC proliferation and ECM production [112].

Recently, a study by Xia et al. described the protective role of exosomes in a rabbit IDD model. Exosomes inhibited $\mathrm{H}_{2} \mathrm{O}_{2}$-induced NLRP3 inflammasome activation, drastically reduced the catabolic action of MMP-3, MMP-13, IL-6 and inducible nitric oxide synthase (iNOS), repressed reactive oxygen species (ROS) generation and mitochondrial dysfunction was restored [113]. Hingert et al. have reported the potential abilities of MSC-derived EVs in a $3 \mathrm{D}$ in vitro model to improve cell viability, proliferation, ECM production, apoptosis, chondrogenesis and cytokine secretion in NPCs harvested from patients with IDD and chronic LBP [114]. Furthermore, an actual challenge is the potential of engineered EVs to lead NPC towards a healthy NP-like phenotype, decrease catabolism and inflammation, and improve GAG accumulation both in vitro and in vivo.

However, the clinical application of exosomes is still premature, and appropriate strategies will be necessary to exploit exosomes as drug delivery vehicles with high specificity, non-cytotoxic effects and low immunogenicity [67].

\section{The Role of miRNAs in IDD}

Exosomes may be promising diagnostic biomarkers due to their ability to incorporate several molecules including lipids, RNAs and proteins targeting specific recipient cells or tissues [124]. Interestingly, many studies have shown that several miRNAs can be predictive markers for IDDs. miRNAs are single-stranded and small non-coding RNAs that can bind to the $3^{\prime}$-untranslated region ( $3^{\prime}$-UTR) of target mRNA molecules, leading to their translational repression or degradation [125]. They represent key biomolecular players that regulate the expression of several target genes and are involved through various pathways in cell proliferation, apoptosis, immunomodulation, ECM anabolism and catabolism (Figure 4) [126]. 


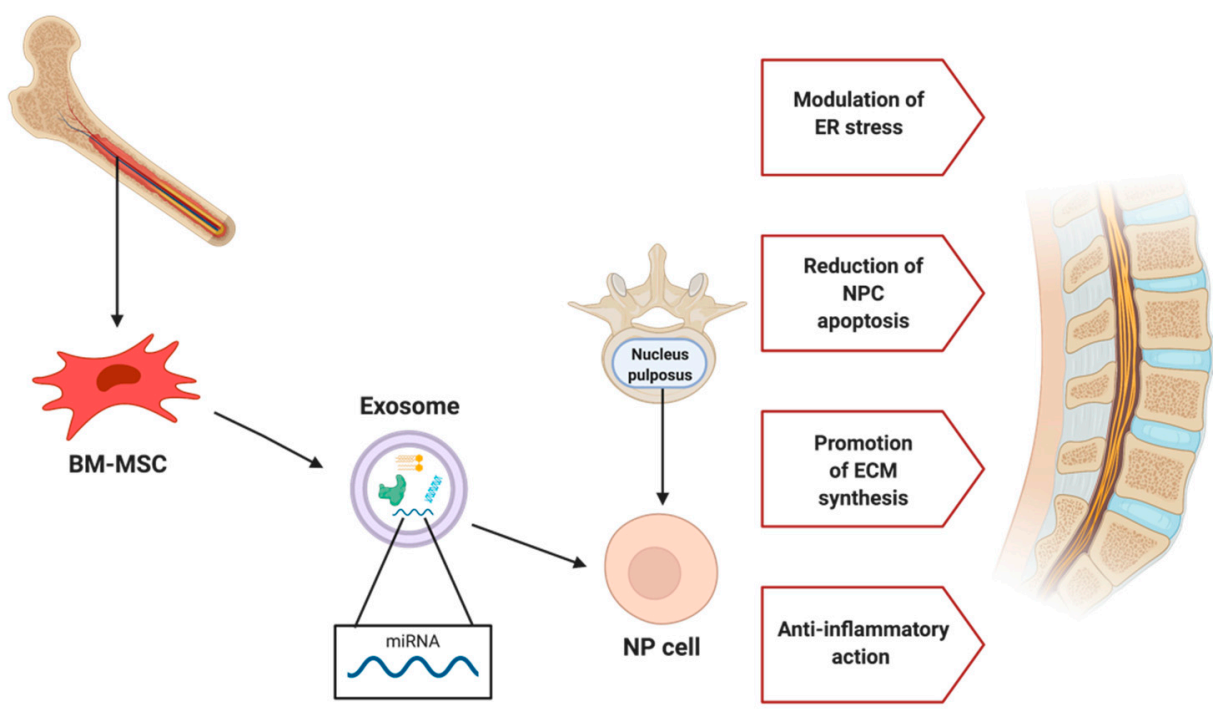

Figure 4. Potential therapeutic role of exosomes in IDD through the modulation of ER stress, stimulation of production of ECM components, anti-apoptotic and anti-inflammatory effects on NP cells. BM-MSCs = bone marrow-derived stem cells; ECM = extracellular matrix; ER = endoplasmic reticulum; NP = nucleus pulposus; NPC = nucleus pulposus cell. Created with BioRender.com (accessed on 10 October 2021).

The anti-apoptotic effects of exosomes from MSCs-derived CM were described in a study conducted by Cheng et al. These results seem to be partially mediated by the transfer of exosomal miR-21 associated with the downregulation of homologous phosphatase and tensin (PTEN), which leads to the activation of the phosphoinositide 3-kinase (PI3K)/ Akt pathway and the inhibition of TNF- $\alpha$-induced NPC apoptosis [127]. The regulatory role of miR-210 was also investigated. Indeed, miR-210 upregulation inhibited apoptosis in human NPCs, suggesting its involvement in the etiology of IDD [128]. It has hypothesized that increased miR-223 expression may be a predictive marker of chronic lumbar radicular pain, as it would be released from the NP following disc herniation [129]. Similarly, the transfection of miR-146a in bovine NPCs decreased IL- $1 \beta$-driven inflammatory and catabolic responses both in vitro and ex vivo [130]. Chen et al. have reported that miR-494-5p was upregulated in NP tissues of a mouse IDD model, while tissue inhibitors of metalloproteinases-3 (TIMP-3) were downregulated. The reduced expression of this miRNA promoted viability and attenuated the apoptosis and senescence of NPCs [131]. The upregulation of miR-142-3p or miR-199 delivered by MSC-derived exosomes may protect NPC from injury through inhibition of mitogen-activated protein kinase (MAPK) signaling [132,133]. In addition, miR-199a decreased MMP-2, MMP-6, TIMP-1 and apoptotic cells in a mouse model of IDD, while the expression of collagen type II, aggrecan, increased following the exposition to BMSC EVs in vitro [134]. Among other miRNAs previously identified, miR-27a was involved in the regulation of apoptotic pathways and in the prevention of IDD through the ability to suppress ECM degradation targeting MMP$13[135,136]$. Similarly, under TNF- $\alpha$ stimulation, exosomes extracted from BM-MSCs were able to secrete miR-532-5p. This exosomal miRNA has been linked to a reduction in apoptosis in NP cells and matrix degradation by targeting Ras association domain family 5 (RASSF5), attenuating disc degeneration [137]. Zhang et al. suggested the potential effect of MSC-derived exosomes on pyroptosis activation and the role of miR-410 as a specific mediator of NPC pyroptosis [138].

Activating transcription factor 6 (ATF6) is a transcription factor identified as the target gene of miR-31-5p. When miR-31-5p was upregulated, the expression of ATF6 and other proteins involved in oxidative stress-induced ER-stress was suppressed, resulting in a protective effect in IDD [139]. 
Another family of molecules delivered by exosomes is represented by circular noncoding RNAs (circRNAs). CircRNAs may act as post-transcriptional regulators and interact with miRNAs as miRNA sponges. In a recent study, the role of exosomal circRNA_0000253 was explored, suggesting that it may competitively absorb miRNA-141-5p and downregulate SIRT1 promoting IDD progression [140].

Further research is required to optimize the effects of MSCs-derived exosomes and to confirm the association of their miRNAs with the pathogenesis of IDD. It will be crucial to know the active components responsible for their actions, underlying mechanisms, pharmacokinetic aspects, and safety of this approach. Table 3 summarizes the different miRNA studied in IVD research.

Table 3. Summary of available evidence on the role of miRNA in IDD.

\begin{tabular}{|c|c|c|c|}
\hline Authors & miRNA & Target Gene & Results \\
\hline Cheng et al. [127] & miR-21 & PTEN & $\begin{array}{l}\text { miR-21 alleviated TNF- } \alpha \text { induced NPC } \\
\text { apoptosis by inhibiting PTEN }\end{array}$ \\
\hline Zhang et al. [128] & miR-210 & HOXA9 & $\begin{array}{l}\text { miR-210 significantly decreased NPC } \\
\text { apoptosis via downregulation of HOXA9 }\end{array}$ \\
\hline Moen et al. [129] & miR-223 & - & $\begin{array}{c}\text { miR-223 may be a predictive biomarker } \\
\text { associated with persistent lumbar } \\
\text { radicular pain }\end{array}$ \\
\hline Gu et al. [130] & miR-146a & TRAF6/IRAK-1 & $\begin{array}{c}\text { An increase in miR-146a protects against } \\
\text { IL-1 induced IVD degeneration and } \\
\text { inflammation }\end{array}$ \\
\hline Chen et al. [131] & miR-494-5p & TIMP-3 & $\begin{array}{l}\text { A dysregulation of miR-494-5p could } \\
\text { decelerate the progression of IDD via } \\
\text { promoting the expression of TIMP3 }\end{array}$ \\
\hline Zhu et al. [132] & miR-142-3p & MLK3 & $\begin{array}{l}\text { Inhibition of inflammation, cell apoptosis, } \\
\text { and MAPK signaling activation in NPCs } \\
\text { through the downregulation of MLK3 }\end{array}$ \\
\hline Wang et al. [133] & miR-199 & MAP3K5 & $\begin{array}{l}\text { TNF- } \alpha \text { induced NPC apoptosis by } \\
\text { downregulating MAP3K5 }\end{array}$ \\
\hline Wen et al. [134] & miR-199a & GREM1 & $\begin{array}{l}\text { miR-199a carried by BM-MSC EVs } \\
\text { promotes IVD repair by targeting GREM1 } \\
\text { and downregulating the TGF- } \beta \text { pathway }\end{array}$ \\
\hline Liu et al. [135] & $\operatorname{miR}-27 a$ & PI3K/MMP-13 & $\begin{array}{l}\text { Upregulation of miR-27a promotes } \\
\text { apoptosis in human IVD by targeting PI3K }\end{array}$ \\
\hline Zhang et al. [136] & $\operatorname{miR}-27 a$ & PI3K/MMP-13 & $\begin{array}{l}\text { miR-27a suppressed ECM degradation and } \\
\text { MMP-13 expression induced by IL-1 } \beta \text { in } \\
\text { NP cells }\end{array}$ \\
\hline Zhu et al. [137] & miR-532-5p & RASSF5 & $\begin{array}{l}\text { Suppression of TNF- } \alpha \text {-induced apoptosis, } \\
\text { ECM degradation, and fibrosis in NPCs }\end{array}$ \\
\hline Zhang et al. [138] & miR-140 & NLRP3 & $\begin{array}{c}\text { miR-410 delivered by MSC exosomes may } \\
\text { inhibit NLRP3 inflammasome-mediated } \\
\text { pyroptosis in NPCs }\end{array}$ \\
\hline Xie et al. [139] & $\operatorname{miR}-31-5 p$ & ATF6 & $\begin{array}{c}\text { MSC exosomes negatively regulated ER } \\
\text { stress, apoptosis and calcification in CEP } \\
\text { through miR-31-5p }\end{array}$ \\
\hline
\end{tabular}

$\mathrm{ATF}=$ activating transcription factor; $\mathrm{BM}-\mathrm{MSC}$ = bone marrow-derived mesenchymal stem cells; $\mathrm{CEP}=$ cartilaginous endplate; $\mathrm{ECM}=$ extracellular matrix; EVs = extracellular vesicles; GREM = gremlin; HOX = homeobox; IL = interleukin; IRAK = interleukin 1 receptor associated kinase; IDD = intervertebral disc degeneration; IVD = intervertebral disc; MAPK = mitogen-activated protein kinase; $\mathrm{MLK}=$ mixed-lineage protein kinase; $\mathrm{MMP}=$ matrix metalloproteinase; $\mathrm{NLRP}=$ nucleotide-binding oligomerization domain, leucine rich repeat and pyrin domain containing; $\mathrm{NPC}=$ nucleus pulposus cell; $\mathrm{PI} 3 \mathrm{~K}=$ phosphoinositide 3-kinase; $\mathrm{PTEN}=$ phosphatase and tensin homolog; RASSF $=$ Ras association domain family; TGF = transforming growth factor; TIMP = tissue inhibitor of metalloproteinases; TNF = tumor necrosis factor; TRAF $=$ tumor necrosis factor receptor-associated factor. 


\section{Conclusions}

In recent years, the transplantation of adult MSCs has been considered a promising approach for IVD tissue regeneration due to their capacity to secrete growth factors, cytokines, and other molecules with paracrine activity. However, the success of MSC-based therapies depends on the survival rate and functionality of transplanted cells within the harsh IVD microenvironment. A growing number of clinical trials have opted for cell therapy, even though there are still many doubts about their routine clinical application.

The use of cell-free therapies could circumvent many obstacles. Numerous studies have recently shown that EVs are released by many cell types including MSCs. These small vesicles can transfer functional proteins, RNA, miRNAs, and lipids among cells, hence promoting intercellular communication, proliferation, inhibition of apoptosis and tissue damage repair. Exosomes represent a promising alternative to traditional stem cell-based therapies. Interestingly, exosomal miRNAs may be predictive biomarkers that regulate the balance between regeneration and degeneration mechanisms in IDD. However, due to many unknown pathophysiological processes in which exosomes are involved, further studies are necessary to confirm the ability of these nanoparticles to promote IVD health and homeostasis.

Author Contributions: Conceptualization, V.T., G.V.; methodology, V.T.; data curation, V.T., C.C., G.D.G.; writing—original draft preparation, V.T.; writing—review and editing, G.V., L.A., F.R., C.C., G.D.G.; supervision, R.P., V.D. All authors have read and agreed to the published version of the manuscript.

Funding: This research received no external funding.

Institutional Review Board Statement: Not applicable.

Informed Consent Statement: Not applicable.

Data Availability Statement: The datasets used and/or analyzed during the current study are available from the corresponding author on reasonable request.

Acknowledgments: The support by the ACTIVE (ClinicalTrials.gov Identifier: NCT04759105), DREAM (ClinicalTrials.gov Identifier: NCT05066334), RESPINE (ClinicalTrials.gov Identifier: NCT03737461) and iPSspine (European Union's Horizon 2020 Research and Innovation Programme under grant agreement no. 825925) projects are gratefully acknowledged.

Conflicts of Interest: The authors declare no conflict of interest.

\section{References}

1. Hoy, D.; Bain, C.; Williams, G.; March, L.; Brooks, P.; Blyth, F.; Woolf, A.; Vos, T.; Buchbinder, R. A systematic review of the global prevalence of low back pain. Arthritis Rheum 2012, 64, 2028-2037. [CrossRef]

2. Fernandez-Moure, J.; Moore, C.A.; Kim, K.; Karim, A.; Smith, K.; Barbosa, Z.; Van Eps, J.; Rameshwar, P.; Weiner, B. Novel therapeutic strategies for degenerative disc disease: Review of cell biology and intervertebral disc cell therapy. SAGE Open Med. 2018, 6, 2050312118761674. [CrossRef] [PubMed]

3. Schneider, B.J.; Haring, R.S.; Song, A.; Kim, P.; Ayers, G.D.; Kennedy, D.J.; Jain, N.B. Characteristics of ambulatory spine care visits in the United States, 2009-2016. J. Back Musculoskelet. Rehabil. 2021, 34, 657-664. [CrossRef]

4. Russo, F.; De Salvatore, S.; Ambrosio, L.; Vadala, G.; Fontana, L.; Papalia, R.; Rantanen, J.; Iavicoli, S.; Denaro, V. Does Workers' Compensation Status Affect Outcomes after Lumbar Spine Surgery? A Systematic Review and Meta-Analysis. Int. J. Environ. Res. Public Health 2021, 18, 6165. [CrossRef]

5. Cassidy, J.J.; Hiltner, A.; Baer, E. Hierarchical structure of the intervertebral disc. Connect. Tissue Res. 1989, 23, 75-88. [CrossRef] [PubMed]

6. Bruehlmann, S.B.; Rattner, J.B.; Matyas, J.R.; Duncan, N.A. Regional variations in the cellular matrix of the annulus fibrosus of the intervertebral disc. J. Anat. 2002, 201, 159-171. [CrossRef] [PubMed]

7. Trout, J.J.; Buckwalter, J.A.; Moore, K.C.; Landas, S.K. Ultrastructure of the human intervertebral disc. I. Changes in notochordal cells with age. Tissue Cell 1982, 14, 359-369. [CrossRef]

8. Risbud, M.V.; Guttapalli, A.; Tsai, T.T.; Lee, J.Y.; Danielson, K.G.; Vaccaro, A.R.; Albert, T.J.; Gazit, Z.; Gazit, D.; Shapiro, I.M. Evidence for skeletal progenitor cells in the degenerate human intervertebral disc. Spine (Phila Pa 1976) 2007, 32, 2537-2544. [CrossRef] 
9. Vadala, G.; Russo, F.; Ambrosio, L.; Loppini, M.; Denaro, V. Stem cells sources for intervertebral disc regeneration. World J. Stem Cells 2016, 8, 185-201. [CrossRef]

10. Vadala, G.; Russo, F.; Di Martino, A.; Denaro, V. Intervertebral disc regeneration: From the degenerative cascade to molecular therapy and tissue engineering. J. Tissue Eng. Regen Med. 2015, 9, 679-690. [CrossRef]

11. Sowa, G.; Westrick, E.; Pacek, C.; Coelho, P.; Patel, D.; Vadala, G.; Georgescu, H.; Vo, N.; Studer, R.; Kang, J. In vitro and in vivo testing of a novel regulatory system for gene therapy for intervertebral disc degeneration. Spine (Phila Pa 1976) 2011, 36, E623-E628. [CrossRef]

12. Hubert, M.G.; Vadala, G.; Sowa, G.; Studer, R.K.; Kang, J.D. Gene therapy for the treatment of degenerative disk disease. J. Am. Acad. Orthop. Surg. 2008, 16, 312-319. [CrossRef]

13. Vadala, G.; Russo, F.; Musumeci, M.; D’Este, M.; Cattani, C.; Catanzaro, G.; Tirindelli, M.C.; Lazzari, L.; Alini, M.; Giordano, R.; et al. Clinically relevant hydrogel-based on hyaluronic acid and platelet rich plasma as a carrier for mesenchymal stem cells: Rheological and biological characterization. J. Orthop. Res. 2017, 35, 2109-2116. [CrossRef] [PubMed]

14. Russo, F.; Ambrosio, L.; Peroglio, M.; Guo, W.; Wangler, S.; Gewiess, J.; Grad, S.; Alini, M.; Papalia, R.; Vadala, G.; et al. A Hyaluronan and Platelet-Rich Plasma Hydrogel for Mesenchymal Stem Cell Delivery in the Intervertebral Disc: An Organ Culture Study. Int. J. Mol. Sci. 2021, 22, 2963. [CrossRef] [PubMed]

15. Vadala, G.; Sowa, G.A.; Smith, L.; Hubert, M.G.; Levicoff, E.A.; Denaro, V.; Gilbertson, L.G.; Kang, J.D. Regulation of transgene expression using an inducible system for improved safety of intervertebral disc gene therapy. Spine (Phila Pa 1976) 2007, 32, 1381-1387. [CrossRef]

16. Vadala, G.; Sowa, G.A.; Kang, J.D. Gene therapy for disc degeneration. Expert Opin. Biol. Ther. 2007, 7, 185-196. [CrossRef] [PubMed]

17. Vadala, G.; Ambrosio, L.; Russo, F.; Papalia, R.; Denaro, V. Interaction between Mesenchymal Stem Cells and Intervertebral Disc Microenvironment: From Cell Therapy to Tissue Engineering. Stem Cells Int. 2019, 2019, 2376172. [CrossRef]

18. Cai, Q.; Zhu, A.; Gong, L. Exosomes of glioma cells deliver miR-148a to promote proliferation and metastasis of glioblastoma via targeting CADM1. Bull. Cancer 2018, 105, 643-651. [CrossRef]

19. Kim, K.H.; Jo, J.H.; Cho, H.J.; Park, T.S.; Kim, T.M. Therapeutic potential of stem cell-derived extracellular vesicles in osteoarthritis: Preclinical study findings. Lab. Anim Res. 2020, 36, 10. [CrossRef]

20. Yanez-Mo, M.; Siljander, P.R.; Andreu, Z.; Zavec, A.B.; Borras, F.E.; Buzas, E.I.; Buzas, K.; Casal, E.; Cappello, F.; Carvalho, J.; et al. Biological properties of extracellular vesicles and their physiological functions. J. Extracell Vesicles 2015, 4, 27066. [CrossRef]

21. Qin, Y.; Sun, R.; Wu, C.; Wang, L.; Zhang, C. Exosome: A Novel Approach to Stimulate Bone Regeneration through Regulation of Osteogenesis and Angiogenesis. Int. J. Mol. Sci. 2016, 17, 712. [CrossRef] [PubMed]

22. Wu, X.; Wang, Y.; Xiao, Y.; Crawford, R.; Mao, X.; Prasadam, I. Extracellular vesicles: Potential role in osteoarthritis regenerative medicine. J. Orthop. Transl. 2020, 21, 73-80. [CrossRef]

23. Pattappa, G.; Li, Z.; Peroglio, M.; Wismer, N.; Alini, M.; Grad, S. Diversity of intervertebral disc cells: Phenotype and function. J. Anat. 2012, 221, 480-496. [CrossRef] [PubMed]

24. Rajasekaran, S.; Vidyadhara, S.; Subbiah, M.; Kamath, V.; Karunanithi, R.; Shetty, A.P.; Venkateswaran, K.; Babu, M.; Meenakshi, J. ISSLS prize winner: A study of effects of in vivo mechanical forces on human lumbar discs with scoliotic disc as a biological model: Results from serial postcontrast diffusion studies, histopathology and biochemical analysis of twenty-one human lumbar scoliotic discs. Spine (Phila Pa 1976) 2010, 35, 1930-1943. [CrossRef]

25. Bartels, E.M.; Fairbank, J.C.; Winlove, C.P.; Urban, J.P. Oxygen and lactate concentrations measured in vivo in the intervertebral discs of patients with scoliosis and back pain. Spine (Phila Pa 1976) 1998, 23, 1-7. [CrossRef]

26. Selard, E.; Shirazi-Adl, A.; Urban, J.P. Finite element study of nutrient diffusion in the human intervertebral disc. Spine (Phila Pa 1976) 2003, 28, 1945-1953. [CrossRef]

27. Bez, M.; Zhou, Z.; Sheyn, D.; Tawackoli, W.; Giaconi, J.C.; Shapiro, G.; Ben David, S.; Gazit, Z.; Pelled, G.; Li, D.; et al. Molecular pain markers correlate with $\mathrm{pH}$-sensitive MRI signal in a pig model of disc degeneration. Sci. Rep. 2018, 8, 17363. [CrossRef]

28. Molinos, M.; Almeida, C.R.; Caldeira, J.; Cunha, C.; Goncalves, R.M.; Barbosa, M.A. Inflammation in intervertebral disc degeneration and regeneration. J. R. Soc. Interface 2015, 12, 20141191. [CrossRef] [PubMed]

29. Johnson, Z.I.; Shapiro, I.M.; Risbud, M.V. Extracellular osmolarity regulates matrix homeostasis in the intervertebral disc and articular cartilage: Evolving role of TonEBP. Matrix Biol. 2014, 40, 10-16. [CrossRef]

30. Urban, J.P. The role of the physicochemical environment in determining disc cell behaviour. Biochem. Soc. Trans. 2002, 30, 858-864. [CrossRef] [PubMed]

31. Wuertz, K.; Urban, J.P.; Klasen, J.; Ignatius, A.; Wilke, H.J.; Claes, L.; Neidlinger-Wilke, C. Influence of extracellular osmolarity and mechanical stimulation on gene expression of intervertebral disc cells. J. Orthop. Res. 2007, 25, 1513-1522. [CrossRef] [PubMed]

32. Tao, Y.Q.; Liang, C.Z.; Li, H.; Zhang, Y.J.; Li, F.C.; Chen, G.; Chen, Q.X. Potential of co-culture of nucleus pulposus mesenchymal stem cells and nucleus pulposus cells in hyperosmotic microenvironment for intervertebral disc regeneration. Cell Biol. Int. 2013, 37, 826-834. [CrossRef] [PubMed]

33. Desmoulin, G.T.; Pradhan, V.; Milner, T.E. Mechanical Aspects of Intervertebral Disc Injury and Implications on Biomechanics. Spine (Phila Pa 1976) 2020, 45, E457-E464. [CrossRef] [PubMed]

34. Fearing, B.V.; Hernandez, P.A.; Setton, L.A.; Chahine, N.O. Mechanotransduction and cell biomechanics of the intervertebral disc. JOR Spine 2018, 1. [CrossRef] [PubMed] 
35. Vo, N.V.; Hartman, R.A.; Patil, P.R.; Risbud, M.V.; Kletsas, D.; Iatridis, J.C.; Hoyland, J.A.; Le Maitre, C.L.; Sowa, G.A.; Kang, J.D. Molecular mechanisms of biological aging in intervertebral discs. J. Orthop. Res. 2016, 34, 1289-1306. [CrossRef]

36. Risbud, M.V.; Shapiro, I.M. Role of cytokines in intervertebral disc degeneration: Pain and disc content. Nat. Rev. Rheumatol. 2014, 10, 44-56. [CrossRef]

37. Wang, Y.; Che, M.; Xin, J.; Zheng, Z.; Li, J.; Zhang, S. The role of IL-1beta and TNF-alpha in intervertebral disc degeneration. Biomed. Pharmacother. 2020, 131, 110660. [CrossRef]

38. Wang, C.; Yu, X.; Yan, Y.; Yang, W.; Zhang, S.; Xiang, Y.; Zhang, J.; Wang, W. Tumor necrosis factor-alpha: A key contributor to intervertebral disc degeneration. Acta Biochim. Biophys. Sin. (Shanghai) 2017, 49, 1-13. [CrossRef] [PubMed]

39. Kadow, T.; Sowa, G.; Vo, N.; Kang, J.D. Molecular basis of intervertebral disc degeneration and herniations: What are the important translational questions? Clin. Orthop. Relat. Res. 2015, 473, 1903-1912. [CrossRef]

40. Urban, J.P.; Smith, S.; Fairbank, J.C. Nutrition of the intervertebral disc. Spine (Phila Pa 1976) 2004, 29, 2700-2709. [CrossRef]

41. Sakai, D.; Nakamura, Y.; Nakai, T.; Mishima, T.; Kato, S.; Grad, S.; Alini, M.; Risbud, M.V.; Chan, D.; Cheah, K.S.; et al. Exhaustion of nucleus pulposus progenitor cells with ageing and degeneration of the intervertebral disc. Nat. Commun. 2012, 3, 1264. [CrossRef]

42. Acaroglu, E.R.; Iatridis, J.C.; Setton, L.A.; Foster, R.J.; Mow, V.C.; Weidenbaum, M. Degeneration and aging affect the tensile behavior of human lumbar anulus fibrosus. Spine (Phila Pa 1976) 1995, 20, 2690-2701. [CrossRef]

43. Liu, Y.; Li, Y.; Nan, L.P.; Wang, F.; Zhou, S.F.; Feng, X.M.; Liu, H.; Zhang, L. Insights of stem cell-based endogenous repair of intervertebral disc degeneration. World J. Stem Cells 2020, 12, 266-276. [CrossRef]

44. Sobajima, S.; Vadala, G.; Shimer, A.; Kim, J.S.; Gilbertson, L.G.; Kang, J.D. Feasibility of a stem cell therapy for intervertebral disc degeneration. Spine J. 2008, 8, 888-896. [CrossRef] [PubMed]

45. Cunha, C.; Almeida, C.R.; Almeida, M.I.; Silva, A.M.; Molinos, M.; Lamas, S.; Pereira, C.L.; Teixeira, G.Q.; Monteiro, A.T.; Santos, S.G.; et al. Systemic Delivery of Bone Marrow Mesenchymal Stem Cells for In Situ Intervertebral Disc Regeneration. Stem Cells Transl. Med. 2017, 6, 1029-1039. [CrossRef] [PubMed]

46. Wangler, S.; Peroglio, M.; Menzel, U.; Benneker, L.M.; Haglund, L.; Sakai, D.; Alini, M.; Grad, S. Mesenchymal Stem Cell Homing Into Intervertebral Discs Enhances the Tie2-positive Progenitor Cell Population, Prevents Cell Death, and Induces a Proliferative Response. Spine (Phila Pa 1976) 2019, 44, 1613-1622. [CrossRef] [PubMed]

47. Vadala, G.; Studer, R.K.; Sowa, G.; Spiezia, F.; Iucu, C.; Denaro, V.; Gilbertson, L.G.; Kang, J.D. Coculture of bone marrow mesenchymal stem cells and nucleus pulposus cells modulate gene expression profile without cell fusion. Spine (Phila Pa 1976) 2008, 33, 870-876. [CrossRef]

48. Vadala, G.; Sobajima, S.; Lee, J.Y.; Huard, J.; Denaro, V.; Kang, J.D.; Gilbertson, L.G. In vitro interaction between muscle-derived stem cells and nucleus pulposus cells. Spine J. 2008, 8, 804-809. [CrossRef]

49. Vadala, G.; Ambrosio, L.; Russo, F.; Papalia, R.; Denaro, V. Stem Cells and Intervertebral Disc Regeneration Overview-What They Can and Can't Do. Int. J. Spine Surg. 2021, 15, 40-53. [CrossRef]

50. Orozco, L.; Soler, R.; Morera, C.; Alberca, M.; Sanchez, A.; Garcia-Sancho, J. Intervertebral disc repair by autologous mesenchymal bone marrow cells: A pilot study. Transplantation 2011, 92, 822-828. [CrossRef]

51. Noriega, D.C.; Ardura, F.; Hernandez-Ramajo, R.; Martin-Ferrero, M.A.; Sanchez-Lite, I.; Toribio, B.; Alberca, M.; Garcia, V.; Moraleda, J.M.; Sanchez, A.; et al. Intervertebral Disc Repair by Allogeneic Mesenchymal Bone Marrow Cells: A Randomized Controlled Trial. Transplantation 2017, 101, 1945-1951. [CrossRef]

52. Rani, S.; Ryan, A.E.; Griffin, M.D.; Ritter, T. Mesenchymal Stem Cell-derived Extracellular Vesicles: Toward Cell-free Therapeutic Applications. Mol. Ther. 2015, 23, 812-823. [CrossRef]

53. Gnecchi, M.; Danieli, P.; Malpasso, G.; Ciuffreda, M.C. Paracrine Mechanisms of Mesenchymal Stem Cells in Tissue Repair. Methods Mol. Biol. 2016, 1416, 123-146. [CrossRef] [PubMed]

54. Harrell, C.R.; Fellabaum, C.; Jovicic, N.; Djonov, V.; Arsenijevic, N.; Volarevic, V. Molecular Mechanisms Responsible for Therapeutic Potential of Mesenchymal Stem Cell-Derived Secretome. Cells 2019, 8, 467. [CrossRef]

55. Wu, L.; Leijten, J.C.; Georgi, N.; Post, J.N.; van Blitterswijk, C.A.; Karperien, M. Trophic effects of mesenchymal stem cells increase chondrocyte proliferation and matrix formation. Tissue Eng. Part A 2011, 17, 1425-1436. [CrossRef] [PubMed]

56. Teixeira, G.Q.; Pereira, C.L.; Ferreira, J.R.; Maia, A.F.; Gomez-Lazaro, M.; Barbosa, M.A.; Neidlinger-Wilke, C.; Goncalves, R.M. Immunomodulation of Human Mesenchymal Stem/Stromal Cells in Intervertebral Disc Degeneration: Insights From a Proinflammatory/Degenerative Ex Vivo Model. Spine (Phila Pa 1976) 2018, 43, E673-E682. [CrossRef]

57. Eseonu, O.I.; De Bari, C. Homing of mesenchymal stem cells: Mechanistic or stochastic? Implications for targeted delivery in arthritis. Rheumatology 2015, 54, 210-218. [CrossRef]

58. Sakai, D.; Schol, J. Cell therapy for intervertebral disc repair: Clinical perspective. J. Orthop. Transl. 2017, 9, 8-18. [CrossRef]

59. Shim, E.K.; Lee, J.S.; Kim, D.E.; Kim, S.K.; Jung, B.J.; Choi, E.Y.; Kim, C.S. Autogenous Mesenchymal Stem Cells from the Vertebral Body Enhance Intervertebral Disc Regeneration via Paracrine Interaction: An in Vitro Pilot Study. Cell Transplant. 2016, 25, 1819-1832. [CrossRef] [PubMed]

60. Li, X.; Wu, A.; Han, C.; Chen, C.; Zhou, T.; Zhang, K.; Yang, X.; Chen, Z.; Qin, A.; Tian, H.; et al. Bone marrow-derived mesenchymal stem cells in three-dimensional co-culture attenuate degeneration of nucleus pulposus cells. Aging (Albany NY) 2019, 11, 9167-9187. [CrossRef] 
61. Guerrero, J.; Hackel, S.; Croft, A.S.; Hoppe, S.; Albers, C.E.; Gantenbein, B. The nucleus pulposus microenvironment in the intervertebral disc: The fountain of youth? Eur. Cell Mater. 2021, 41, 707-738. [CrossRef] [PubMed]

62. Miguelez-Rivera, L.; Perez-Castrillo, S.; Gonzalez-Fernandez, M.L.; Prieto-Fernandez, J.G.; Lopez-Gonzalez, M.E.; Garcia-Cosamalon, J.; Villar-Suarez, V. Immunomodulation of mesenchymal stem cells in discogenic pain. Spine J. 2018, 18, 330-342. [CrossRef] [PubMed]

63. Loibl, M.; Wuertz-Kozak, K.; Vadalà, G.; Lang, S.; Fairbank, J.; Urban, J.P. Controversies in regenerative medicine: Should intervertebral disc degeneration be treated with mesenchymal stem cells? JOR Spine 2019, 2, e1043. [CrossRef]

64. Johnstone, R.M.; Adam, M.; Hammond, J.R.; Orr, L.; Turbide, C. Vesicle formation during reticulocyte maturation. Association of plasma membrane activities with released vesicles (exosomes). J. Biol. Chem. 1987, 262, 9412-9420. [CrossRef]

65. Thery, C.; Witwer, K.W.; Aikawa, E.; Alcaraz, M.J.; Anderson, J.D.; Andriantsitohaina, R.; Antoniou, A.; Arab, T.; Archer, F.; Atkin-Smith, G.K.; et al. Minimal information for studies of extracellular vesicles 2018 (MISEV2018): A position statement of the International Society for Extracellular Vesicles and update of the MISEV2014 guidelines. J. Extracell Vesicles 2018, 7, 1535750. [CrossRef]

66. Crescitelli, R.; Lasser, C.; Szabo, T.G.; Kittel, A.; Eldh, M.; Dianzani, I.; Buzas, E.I.; Lotvall, J. Distinct RNA profiles in subpopulations of extracellular vesicles: Apoptotic bodies, microvesicles and exosomes. J. Extracell Vesicles 2013, 2. [CrossRef]

67. Buschmann, D.; Mussack, V.; Byrd, J.B. Separation, characterization, and standardization of extracellular vesicles for drug delivery applications. Adv. Drug. Deliv. Rev. 2021, 174, 348-368. [CrossRef]

68. Wolf, P. The nature and significance of platelet products in human plasma. Br. J. Haematol. 1967, 13, 269-288. [CrossRef]

69. Akers, J.C.; Gonda, D.; Kim, R.; Carter, B.S.; Chen, C.C. Biogenesis of extracellular vesicles (EV): Exosomes, microvesicles, retrovirus-like vesicles, and apoptotic bodies. J. Neurooncol. 2013, 113, 1-11. [CrossRef]

70. Thery, C.; Zitvogel, L.; Amigorena, S. Exosomes: Composition, biogenesis and function. Nat. Rev. Immunol. 2002, 2, 569-579. [CrossRef]

71. Zhang, Y.; Liu, Y.; Liu, H.; Tang, W.H. Exosomes: Biogenesis, biologic function and clinical potential. Cell Biosci. 2019, 9, 19. [CrossRef] [PubMed]

72. Zhang, B.; Tian, X.; Hao, J.; Xu, G.; Zhang, W. Mesenchymal Stem Cell-Derived Extracellular Vesicles in Tissue Regeneration. Cell Transplant. 2020, 29, 963689720908500. [CrossRef]

73. Xu, R.; Greening, D.W.; Zhu, H.J.; Takahashi, N.; Simpson, R.J. Extracellular vesicle isolation and characterization: Toward clinical application. J. Clin. Investig. 2016, 126, 1152-1162. [CrossRef]

74. Jurj, A.; Zanoaga, O.; Braicu, C.; Lazar, V.; Tomuleasa, C.; Irimie, A.; Berindan-Neagoe, I. A Comprehensive Picture of Extracellular Vesicles and Their Contents. Molecular Transfer to Cancer Cells. Cancers 2020, 12, 298. [CrossRef]

75. Brouwers, J.F.; Aalberts, M.; Jansen, J.W.; van Niel, G.; Wauben, M.H.; Stout, T.A.; Helms, J.B.; Stoorvogel, W. Distinct lipid compositions of two types of human prostasomes. Proteomics 2013, 13, 1660-1666. [CrossRef] [PubMed]

76. Balaj, L.; Lessard, R.; Dai, L.; Cho, Y.J.; Pomeroy, S.L.; Breakefield, X.O.; Skog, J. Tumour microvesicles contain retrotransposon elements and amplified oncogene sequences. Nat. Commun. 2011, 2, 180. [CrossRef] [PubMed]

77. Thakur, B.K.; Zhang, H.; Becker, A.; Matei, I.; Huang, Y.; Costa-Silva, B.; Zheng, Y.; Hoshino, A.; Brazier, H.; Xiang, J.; et al. Double-stranded DNA in exosomes: A novel biomarker in cancer detection. Cell Res. 2014, 24, 766-769. [CrossRef] [PubMed]

78. Pegtel, D.M.; Gould, S.J. Exosomes. Annu. Rev. Biochem. 2019, 88, 487-514. [CrossRef]

79. Valadi, H.; Ekstrom, K.; Bossios, A.; Sjostrand, M.; Lee, J.J.; Lotvall, J.O. Exosome-mediated transfer of mRNAs and microRNAs is a novel mechanism of genetic exchange between cells. Nat. Cell Biol. 2007, 9, 654-659. [CrossRef]

80. Lai, R.C.; Tan, S.S.; Yeo, R.W.; Choo, A.B.; Reiner, A.T.; Su, Y.; Shen, Y.; Fu, Z.; Alexander, L.; Sze, S.K.; et al. MSC secretes at least $3 \mathrm{EV}$ types each with a unique permutation of membrane lipid, protein and RNA. J. Extracell Vesicles 2016, 5, 29828. [CrossRef]

81. Colombo, M.; Raposo, G.; Thery, C. Biogenesis, secretion, and intercellular interactions of exosomes and other extracellular vesicles. Annu. Rev. Cell Dev. Biol. 2014, 30, 255-289. [CrossRef] [PubMed]

82. Raposo, G.; Stoorvogel, W. Extracellular vesicles: Exosomes, microvesicles, and friends. J. Cell Biol. 2013, 200, 373-383. [CrossRef] [PubMed]

83. Piccin, A.; Murphy, W.G.; Smith, O.P. Circulating microparticles: Pathophysiology and clinical implications. Blood Rev. 2007, 21, 157-171. [CrossRef] [PubMed]

84. del Conde, I.; Shrimpton, C.N.; Thiagarajan, P.; López, J.A. Tissue-factor-bearing microvesicles arise from lipid rafts and fuse with activated platelets to initiate coagulation. Blood 2005, 106, 1604-1611. [CrossRef] [PubMed]

85. Li, B.; Antonyak, M.A.; Zhang, J.; Cerione, R.A. RhoA triggers a specific signaling pathway that generates transforming microvesicles in cancer cells. Oncogene 2012, 31, 4740-4749. [CrossRef] [PubMed]

86. Colombo, M.; Moita, C.; van Niel, G.; Kowal, J.; Vigneron, J.; Benaroch, P.; Manel, N.; Moita, L.F.; Thery, C.; Raposo, G. Analysis of ESCRT functions in exosome biogenesis, composition and secretion highlights the heterogeneity of extracellular vesicles. J. Cell Sci. 2013, 126, 5553-5565. [CrossRef]

87. Tamai, K.; Tanaka, N.; Nakano, T.; Kakazu, E.; Kondo, Y.; Inoue, J.; Shiina, M.; Fukushima, K.; Hoshino, T.; Sano, K.; et al. Exosome secretion of dendritic cells is regulated by Hrs, an ESCRT-0 protein. Biochem. Biophys. Res. Commun. 2010, 399, 384-390. [CrossRef]

88. Lo Cicero, A.; Stahl, P.D.; Raposo, G. Extracellular vesicles shuffling intercellular messages: For good or for bad. Curr. Opin. Cell Biol. 2015, 35, 69-77. [CrossRef] 
89. Kowal, J.; Tkach, M.; Thery, C. Biogenesis and secretion of exosomes. Curr. Opin. Cell Biol. 2014, 29, 116-125. [CrossRef]

90. Thery, C.; Boussac, M.; Veron, P.; Ricciardi-Castagnoli, P.; Raposo, G.; Garin, J.; Amigorena, S. Proteomic analysis of dendritic cell-derived exosomes: A secreted subcellular compartment distinct from apoptotic vesicles. J. Immunol. 2001, 166, 7309-7318. [CrossRef]

91. Trajkovic, K.; Hsu, C.; Chiantia, S.; Rajendran, L.; Wenzel, D.; Wieland, F.; Schwille, P.; Brugger, B.; Simons, M. Ceramide triggers budding of exosome vesicles into multivesicular endosomes. Science 2008, 319, 1244-1247. [CrossRef]

92. Baietti, M.F.; Zhang, Z.; Mortier, E.; Melchior, A.; Degeest, G.; Geeraerts, A.; Ivarsson, Y.; Depoortere, F.; Coomans, C.; Vermeiren, E.; et al. Syndecan-syntenin-ALIX regulates the biogenesis of exosomes. Nat. Cell Biol. 2012, 14, 677-685. [CrossRef] [PubMed]

93. Geminard, C.; De Gassart, A.; Blanc, L.; Vidal, M. Degradation of AP2 during reticulocyte maturation enhances binding of hsc70 and Alix to a common site on TFR for sorting into exosomes. Traffic 2004, 5, 181-193. [CrossRef]

94. van Niel, G.; Charrin, S.; Simoes, S.; Romao, M.; Rochin, L.; Saftig, P.; Marks, M.S.; Rubinstein, E.; Raposo, G. The Tetraspanin CD63 Regulates ESCRT-Independent and -Dependent Endosomal Sorting during Melanogenesis. Dev. Cell 2011, $21,708-721$. [CrossRef] [PubMed]

95. Ostrowski, M.; Carmo, N.B.; Krumeich, S.; Fanget, I.; Raposo, G.; Savina, A.; Moita, C.F.; Schauer, K.; Hume, A.N.; Freitas, R.P.; et al. Rab27a and Rab27b control different steps of the exosome secretion pathway. Nat. Cell Biol. 2010, 12, 19-30. [CrossRef]

96. van Niel, G.; D'Angelo, G.; Raposo, G. Shedding light on the cell biology of extracellular vesicles. Nat. Rev. Mol. Cell Biol. 2018, 19, 213-228. [CrossRef] [PubMed]

97. Alvarez-Viejo, M. Mesenchymal stem cells from different sources and their derived exosomes: A pre-clinical perspective. World J. Stem Cells 2020, 12, 100-109. [CrossRef]

98. Richardson, S.M.; Kalamegam, G.; Pushparaj, P.N.; Matta, C.; Memic, A.; Khademhosseini, A.; Mobasheri, R.; Poletti, F.L.; Hoyland, J.A.; Mobasheri, A. Mesenchymal stem cells in regenerative medicine: Focus on articular cartilage and intervertebral disc regeneration. Methods 2016, 99, 69-80. [CrossRef]

99. Elahi, F.M.; Farwell, D.G.; Nolta, J.A.; Anderson, J.D. Preclinical translation of exosomes derived from mesenchymal stem/stromal cells. Stem Cells 2020, 38, 15-21. [CrossRef]

100. Piazza, N.; Dehghani, M.; Gaborski, T.R.; Wuertz-Kozak, K. Therapeutic Potential of Extracellular Vesicles in Degenerative Diseases of the Intervertebral Disc. Front. Bioeng. Biotechnol. 2020, 8, 311. [CrossRef]

101. Pinheiro, A.; Silva, A.M.; Teixeira, J.H.; Goncalves, R.M.; Almeida, M.I.; Barbosa, M.A.; Santos, S.G. Extracellular vesicles: Intelligent delivery strategies for therapeutic applications. J. Control. Release 2018, 289, 56-69. [CrossRef]

102. Thery, C.; Amigorena, S.; Raposo, G.; Clayton, A. Isolation and characterization of exosomes from cell culture supernatants and biological fluids. Curr. Protoc. Cell Biol. 2006, 30, 3-22. [CrossRef] [PubMed]

103. Witwer, K.W.; Buzas, E.I.; Bemis, L.T.; Bora, A.; Lasser, C.; Lotvall, J.; Nolte-'t Hoen, E.N.; Piper, M.G.; Sivaraman, S.; Skog, J.; et al. Standardization of sample collection, isolation and analysis methods in extracellular vesicle research. J. Extracell Vesicles 2013, 2. [CrossRef] [PubMed]

104. Corso, G.; Mager, I.; Lee, Y.; Gorgens, A.; Bultema, J.; Giebel, B.; Wood, M.J.A.; Nordin, J.Z.; Andaloussi, S.E. Reproducible and scalable purification of extracellular vesicles using combined bind-elute and size exclusion chromatography. Sci. Rep. 2017, 7, 11561. [CrossRef]

105. Dehghani, M.; Lucas, K.; Flax, J.; McGrath, J.; Gaborski, T. Tangential flow microfluidics for the capture and release of nanoparticles and extracellular vesicles on conventional and ultrathin membranes. Adv. Mater. Technol. 2019, 4, 1900539. [CrossRef] [PubMed]

106. Taylor, D.D.; Zacharias, W.; Gercel-Taylor, C. Exosome isolation for proteomic analyses and RNA profiling. Methods Mol. Biol. 2011, 728, 235-246. [CrossRef] [PubMed]

107. Doyle, L.M.; Wang, M.Z. Overview of Extracellular Vesicles, Their Origin, Composition, Purpose, and Methods for Exosome Isolation and Analysis. Cells 2019, 8, 727. [CrossRef] [PubMed]

108. Alcaraz, M.J.; Compan, A.; Guillen, M.I. Extracellular Vesicles from Mesenchymal Stem Cells as Novel Treatments for Musculoskeletal Diseases. Cells 2019, 9, 98. [CrossRef]

109. Shi, Y.; Kang, X.; Wang, Y.; Bian, X.; He, G.; Zhou, M.; Tang, K. Exosomes Derived from Bone Marrow Stromal Cells (BMSCs) Enhance Tendon-Bone Healing by Regulating Macrophage Polarization. Med. Sci. Monit. 2020, 26, e923328. [CrossRef]

110. Liao, Z.; Luo, R.; Li, G.; Song, Y.; Zhan, S.; Zhao, K.; Hua, W.; Zhang, Y.; Wu, X.; Yang, C. Exosomes from mesenchymal stem cells modulate endoplasmic reticulum stress to protect against nucleus pulposus cell death and ameliorate intervertebral disc degeneration in vivo. Theranostics 2019, 9, 4084-4100. [CrossRef]

111. Lan, W.R.; Pan, S.; Li, H.Y.; Sun, C.; Chang, X.; Lu, K.; Jiang, C.Q.; Zuo, R.; Zhou, Y.; Li, C.Q. Inhibition of the Notch1 Pathway Promotes the Effects of Nucleus Pulposus Cell-Derived Exosomes on the Differentiation of Mesenchymal Stem Cells into Nucleus Pulposus-Like Cells in Rats. Stem Cells Int. 2019, 2019, 8404168. [CrossRef]

112. Lu, K.; Li, H.Y.; Yang, K.; Wu, J.L.; Cai, X.W.; Zhou, Y.; Li, C.Q. Exosomes as potential alternatives to stem cell therapy for intervertebral disc degeneration: In-vitro study on exosomes in interaction of nucleus pulposus cells and bone marrow mesenchymal stem cells. Stem Cell Res. Ther. 2017, 8, 108. [CrossRef] [PubMed] 
113. Xia, C.; Zeng, Z.; Fang, B.; Tao, M.; Gu, C.; Zheng, L.; Wang, Y.; Shi, Y.; Fang, C.; Mei, S.; et al. Mesenchymal stem cell-derived exosomes ameliorate intervertebral disc degeneration via anti-oxidant and anti-inflammatory effects. Free Radic Biol. Med. 2019, 143, 1-15. [CrossRef]

114. Hingert, D.; Ekstrom, K.; Aldridge, J.; Crescitelli, R.; Brisby, H. Extracellular vesicles from human mesenchymal stem cells expedite chondrogenesis in 3D human degenerative disc cell cultures. Stem Cell Res. Ther. 2020, 11, 323. [CrossRef] [PubMed]

115. Li, M.; Li, R.; Yang, S.; Yang, D.; Gao, X.; Sun, J.; Ding, W.; Ma, L. Exosomes Derived from Bone Marrow Mesenchymal Stem Cells Prevent Acidic pH-Induced Damage in Human Nucleus Pulposus Cells. Med. Sci. Monit. 2020, 26, e922928. [CrossRef]

116. Li, Z.Q.; Kong, L.; Liu, C.; Xu, H.G. Human Bone Marrow Mesenchymal Stem Cell-derived Exosomes Attenuate IL-1beta-induced Annulus Fibrosus Cell Damage. Am. J. Med. Sci. 2020, 360, 693-700. [CrossRef]

117. Luo, L.; Jian, X.; Sun, H.; Qin, J.; Wang, Y.; Zhang, J.; Shen, Z.; Yang, D.; Li, C.; Zhao, P.; et al. Cartilage endplate stem cells inhibit intervertebral disc degeneration by releasing exosomes to nucleus pulposus cells to activate Akt/autophagy. Stem Cells 2021, 39, 467-481. [CrossRef] [PubMed]

118. Luo, L.; Gong, J.; Zhang, H.; Qin, J.; Li, C.; Zhang, J.; Tang, Y.; Zhang, Y.; Chen, J.; Zhou, Y.; et al. Cartilage Endplate Stem Cells Transdifferentiate Into Nucleus Pulposus Cells via Autocrine Exosomes. Front. Cell Dev. Biol. 2021, 9, 648201. [CrossRef]

119. Tang, S.; Salazar-Puerta, A.; Richards, J.; Khan, S.; Hoyland, J.A.; Gallego-Perez, D.; Walter, B.; Higuita-Castro, N.; Purmessur, D. Non-viral reprogramming of human nucleus pulposus cells with FOXF1 via extracellular vesicle delivery: An in vitro and in vivo study. Eur. Cell Mater. 2021, 41, 90-107. [CrossRef]

120. Sun, Z.; Zhao, H.; Liu, B.; Gao, Y.; Tang, W.H.; Liu, Z.H.; Luo, Z.J. AF cell derived exosomes regulate endothelial cell migration and inflammation: Implications for vascularization in intervertebral disc degeneration. Life Sci. 2021, 265, 118778. [CrossRef]

121. Liu, L.T.; Huang, B.; Li, C.Q.; Zhuang, Y.; Wang, J.; Zhou, Y. Characteristics of stem cells derived from the degenerated human intervertebral disc cartilage endplate. PLoS ONE 2011, 6, e26285. [CrossRef] [PubMed]

122. Chiang, C.K.; Wang, C.C.; Lu, T.F.; Huang, K.H.; Sheu, M.L.; Liu, S.H.; Hung, K.Y. Involvement of Endoplasmic Reticulum Stress, Autophagy, and Apoptosis in Advanced Glycation End Products-Induced Glomerular Mesangial Cell Injury. Sci. Rep. 2016, 6, 34167. [CrossRef] [PubMed]

123. Song, Y.; Wang, Y.; Zhang, Y.; Geng, W.; Liu, W.; Gao, Y.; Li, S.; Wang, K.; Wu, X.; Kang, L.; et al. Advanced glycation end products regulate anabolic and catabolic activities via NLRP3-inflammasome activation in human nucleus pulposus cells. J. Cell Mol. Med. 2017, 21, 1373-1387. [CrossRef]

124. Hu, Z.-L.; Li, H.-Y.; Chang, X.; Li, Y.-Y.; Liu, C.-H.; Gao, X.-X.; Zhai, Y.; Chen, Y.-X.; Li, C.-Q. Exosomes derived from stem cells as an emerging therapeutic strategy for intervertebral disc degeneration. World J. Stem Cells 2020, 12, 803-813. [CrossRef]

125. Cazzanelli, P.; Wuertz-Kozak, K. MicroRNAs in Intervertebral Disc Degeneration, Apoptosis, Inflammation, and Mechanobiology. Int. J. Mol. Sci. 2020, 21, 3601. [CrossRef] [PubMed]

126. Wang, X.Q.; Tu, W.Z.; Guo, J.B.; Song, G.; Zhang, J.; Chen, C.C.; Chen, P.J. A Bioinformatic Analysis of MicroRNAs' Role in Human Intervertebral Disc Degeneration. Pain Med. 2019, 20, 2459-2471. [CrossRef]

127. Cheng, X.; Zhang, G.; Zhang, L.; Hu, Y.; Zhang, K.; Sun, X.; Zhao, C.; Li, H.; Li, Y.M.; Zhao, J. Mesenchymal stem cells deliver exogenous miR-21 via exosomes to inhibit nucleus pulposus cell apoptosis and reduce intervertebral disc degeneration. J. Cell Mol. Med. 2018, 22, 261-276. [CrossRef] [PubMed]

128. Zhang, D.Y.; Wang, Z.J.; Yu, Y.B.; Zhang, Y.; Zhang, X.X. Role of microRNA-210 in human intervertebral disc degeneration. Exp. Ther. Med. 2016, 11, 2349-2354. [CrossRef]

129. Moen, A.; Jacobsen, D.; Phuyal, S.; Legfeldt, A.; Haugen, F.; Roe, C.; Gjerstad, J. MicroRNA-223 demonstrated experimentally in exosome-like vesicles is associated with decreased risk of persistent pain after lumbar disc herniation. J. Transl. Med. 2017, 15, 89. [CrossRef]

130. Gu, S.X.; Li, X.; Hamilton, J.L.; Chee, A.; Kc, R.; Chen, D.; An, H.S.; Kim, J.S.; Oh, C.D.; Ma, Y.Z.; et al. MicroRNA-146a reduces IL-1 dependent inflammatory responses in the intervertebral disc. Gene 2015, 555, 80-87. [CrossRef]

131. Chen, G.; Zhou, X.; Li, H.; Xu, Z. Inhibited microRNA-494-5p promotes proliferation and suppresses senescence of nucleus pulposus cells in mice with intervertebral disc degeneration by elevating TIMP3. Cell Cycle 2021, 20, 11-22. [CrossRef]

132. Zhu, L.; Shi, Y.; Liu, L.; Wang, H.; Shen, P.; Yang, H. Mesenchymal stem cells-derived exosomes ameliorate nucleus pulposus cells apoptosis via delivering miR-142-3p: Therapeutic potential for intervertebral disc degenerative diseases. Cell Cycle 2020, 19, 1727-1739. [CrossRef]

133. Wang, W.; Guo, Z.; Yang, S.; Wang, H.; Ding, W. Upregulation of miR-199 attenuates TNF-alpha-induced Human nucleus pulposus cell apoptosis by downregulating MAP3K5. Biochem. Biophys. Res. Commun. 2018, 505, 917-924. [CrossRef]

134. Wen, T.; Wang, H.; Li, Y.; Lin, Y.; Zhao, S.; Liu, J.; Chen, B. Bone mesenchymal stem cell-derived extracellular vesicles promote the repair of intervertebral disc degeneration by transferring microRNA-199a. Cell Cycle 2021, 20, 256-270. [CrossRef] [PubMed]

135. Liu, G.; Cao, P.; Chen, H.; Yuan, W.; Wang, J.; Tang, X. MiR-27a regulates apoptosis in nucleus pulposus cells by targeting PI3K. PLoS ONE 2013, 8, e75251. [CrossRef] [PubMed]

136. Zhang, Q.C.; Hu, S.Q.; Hu, A.N.; Zhang, T.W.; Jiang, L.B.; Li, X.L. Autophagy-activated nucleus pulposus cells deliver exosomal miR-27a to prevent extracellular matrix degradation by targeting MMP-13. J. Orthop. Res. 2021, 39, 1921-1932. [CrossRef]

137. Zhu, G.; Yang, X.; Peng, C.; Yu, L.; Hao, Y. Exosomal miR-532-5p from bone marrow mesenchymal stem cells reduce intervertebral disc degeneration by targeting RASSF5. Exp. Cell Res. 2020, 393, 112109. [CrossRef] [PubMed] 
138. Zhang, J.; Zhang, J.; Zhang, Y.; Liu, W.; Ni, W.; Huang, X.; Yuan, J.; Zhao, B.; Xiao, H.; Xue, F. Mesenchymal stem cells-derived exosomes ameliorate intervertebral disc degeneration through inhibiting pyroptosis. J. Cell Mol. Med. 2020, 24, 11742-11754. [CrossRef]

139. Xie, L.; Chen, Z.; Liu, M.; Huang, W.; Zou, F.; Ma, X.; Tao, J.; Guo, J.; Xia, X.; Lyu, F.; et al. MSC-Derived Exosomes Protect Vertebral Endplate Chondrocytes against Apoptosis and Calcification via the miR-31-5p/ATF6 Axis. Mol. Ther. Nucleic Acids 2020, 22, 601-614. [CrossRef]

140. Song, J.; Chen, Z.H.; Zheng, C.J.; Song, K.H.; Xu, G.Y.; Xu, S.; Zou, F.; Ma, X.S.; Wang, H.L.; Jiang, J.Y. Exosome-Transported circRNA_0000253 Competitively Adsorbs MicroRNA-141-5p and Increases IDD. Mol. Ther. Nucleic Acids 2020, 21, 1087-1099. [CrossRef] 